\title{
Photosensitizing properties of subphthalocyanine derivatives in a poly (methyl methacrylate) film
}

\author{
Eiko $\mathrm{O}_{\text {Hono }}-\mathrm{O}_{\text {Kumura }}{ }^{*}$, Keiichi $\mathrm{S}_{\text {akamoto }}{ }^{* *}$ and Toshiyuki $\mathrm{U}_{\mathrm{RANO}}{ }^{* * *}$
}

\begin{abstract}
The sensitization properties of butylthio- and phenylthio-substituted subphthalocyanines in a poly (methyl methacrylate) film in the presence of 2, 4,6-tris (trichloromethyl)-1,3,5-triazine as a radical generation species was investigated by laser flash photolysis.
\end{abstract}

Key-words : Subphthalocyanine derivatives, Laser flash photolysis

\section{Introduction}

Phthalocyanine derivatives have four isoindole units and a central metal, while subphthalocyanine (SubPC) derivatives consist of three isoindole units and a boron atom in the center.

The synthesis of SubPC and five derivatives such as (dodecylfluoro) subphthalocyanine $\left(\operatorname{SubPCF}_{12}\right)$, [hexakis (butylthio) hexafluoro] subphthalocyanine (SubPC (butyl - S) ${ }_{6} \mathrm{~F}_{6}$ ), dodecylkis (butylthio) subphthalocyanine (SubPC (butyl-S) ${ }_{12}$ ), [hexakis (phenylthio) hexafluor] subphthalocyanine (SubPC(phenyl-S) ${ }_{6} \mathrm{~F}_{6}$ ) and [dodecylkis (phenylthio)] subphthalocyanine $\left(\operatorname{SubPC}(\text { phenyl-S })_{12}\right)$ has been reported in our previous paper $^{1)}$.

SubPC derivatives have been used as intermediates to prepare unsymmetrical phthalocyanine derivatives. SubPC derivatives are generally more photosensitive than phthalocyanine derivatives. Then, SubPC deriva-

Received June 25, 2002

* Research institute of Chemical Science, Technology and Education, 8-37-1 Narashinodai, Funabashi, Chiba 2740063 Japan

** Department of Applied Molecular Chemistry, College of Industrial Technology, Nihon University, 1-2-1 Izumicho, Narashino, Chiba 275-8575 Japan

*** Center for Cooperative Research, Faculty of Engineering, Chiba University, 1-33 Yayoi-cho, Inage-ku, Chiba 263-8522 Japan

Science and Technology Research Center, Mitsubishi Chemical Corporation, 100 Kamoshida-cho, Aoba-ku, Yokohama 227-8502 Japan tives are expected to be used as photosensitizer in the same manner as cyanine dyes are used as sensitizers in silver halide photography.

Photopolymer plates containing a sensitive photoinitiator for a visible laser photopolymerization system can be used for future high-speed laser printing. It is difficult to discuss the photoinitiation mechanism in polymer films on the basis of the data obtained from laser flash photolysis in solution, because of the great difference in mobility of substance between in solution and in polymers. Therefore, the laser analysis of photoinitiator contained in polymer system can provide direct information about photoexcited dyes and radicals in polymers as the simulated condition for practical use of SubPC derivatives.

In the present study, we report photosensitizing properties of SubPC derivatives in a poly (methyl methacrylate) (PMMA) film as a model for developing new sensitizers for future laser printing.

\section{Experimental}

\subsection{Synthesis of subphthalocyanine and its deriva-} tives

A solution of boron trichloride $(20.5 \mathrm{~mL}, 0.02 \mathrm{~mol}, 1$ $\mathrm{M}$ in hexane) was added to the mixture of 1,2-benzenedicarbonitrile derivatives $(0.04 \mathrm{~mol})$ and 1 -chloronaphtahalene $(12 \mathrm{~mL})$ under an argon atmosphere at $3^{\circ} \mathrm{C}$. The reaction mixture was heated to $120^{\circ} \mathrm{C}$ with stirring. Hexane was distilled off. After that the mixture was heated to $250^{\circ} \mathrm{C}$ for $10 \mathrm{~min}$ and cooled to room temperature, the product was extracted with petroleum 
ether for $24 \mathrm{~h}$ and then toluene for $2 \mathrm{~h}$ with a Soxhlet extractor. The product was recrystallized from ethanol. The detailed synthetic results have been reported in the previous paper ${ }^{1)}$.

\subsection{Spectroscopy and laser flash photolysis}

Absorption spectra were recorded on a Shimadzu UV -2400 PC spectrophotometer. Fluorescence spectra were measured on a Hitachi F-4500 fluorescence spectrometer by using a solid sample holder, which was also used for a solution in order to minimize the influence of an internal light filter. Cyclic voltammetry was carried out with a BAS CV-50 W voltammetric analyzer at room temperature in acetonitrile containing a $0.01 \mathrm{~mol} \mathrm{dm}^{-3}$ solution of tetrabutylammonium perchlorate ${ }^{2-4)}$. Cyclic voltammograms were recorded by scanning the potential at the rate of $50 \mathrm{mV} \mathrm{s}^{-1}$. The working and counter electrodes were platinum wires, and the reference electrode was a silver/silver chloride $(\mathrm{Ag} / \mathrm{AgCl})$ saturated sodium chloride ${ }^{5)}$. The area of the working electrode was $2.0 \times 10^{-2} \mathrm{~cm}^{2}$.

Laser flash photolysis of film was performed using a total reflection sapphire cell $(10 \times 30 \mathrm{~mm}, 1 \mathrm{~mm}$ thickness, and both side were cut at a 45 degree angle) ${ }^{6,7)}$, which was spin-coated with a thickness of $1.2 \mu \mathrm{m}$ SubPC-containing 10\% PMMA photopolymer film as shown in Fig. 1. The excitation light pulse from a Spectron Laser System Model SL 402 YAG laser was expanded and exposed over the entire sample cell. A xenon lamp was used as a monitoring beam ${ }^{6,7}$.

The measurement was repeated five times with in 3 wt\% of SubPCs and 2, 4, 6-tris (trichloromethyl)-1, 3, 5 -triazine (TCT) as a radical generator; more than $90 \%$ of the $355 \mathrm{~nm}$-laser light was absorbed by SubPCs.

Films were prepared by taking a 10\% PMMA cyclohexanone solution, and directly adding SubPC to the solution. Film thichness was adjusted to be $1.2 \mu \mathrm{m}$ by spin-coating.

\section{Results and Discussion}

Excitation and fluorescence spectra of SubPC and its derivatives showed similar profile ${ }^{1)}$. Butylthio- and phenylthio-substituted SubPCs were more bathochromic than SubPC ${ }^{1)}$.

The fluorescence of SubPC and its derivatives was efficiently generated by radicals from TCT. A transient absorption of SubPC and its derivatives were observed. The results suggest a static sensitization mechanism of the photoinitiation system.

Fig. 2 shows the photochemical scheme in the system. SubPC and its derivatives act as photosensitizers and TCT as a radical generating reagent by laser irradiation.

Fig. 3 shows the time profiles of the triplet state for SubPC in the PMMA film. The fluorescence peak and transient decay were observed upon the excitation at $355 \mathrm{~nm}$ pulse of a PMMA film containing SubPC. The lifetime of photoexcited triplet state of SubPC was estimated as $20 \mu$ s laser pulse. The transient absorption was assigned as a triplet state ${ }^{8)}$.

Fig. 4 shows a Perrin plot of PC. For the laser excitation of PMMA film at $550 \mathrm{~nm}$, the fluorescence of SubPC was efficiently radical generated by TCT. The relationship, that the fluorescence intensity decreased in direct proportion to the concentration of the $\mathrm{TCT}^{9}$, indicated the Perrin type static quenching process. The quenching radius (Rf) was determined from the slope, and was estimated to be $1.5 \mathrm{~nm}^{10,11)}$.

The multistep equilibrium between SubPC derivatives and TCT is assumed in Equations 1 and 2 (Scheme 1), where, i, Ki and (SubPC-iTCT) are amount of substance, rate constant, and complex of SubPC and TCT, respectively.

Equation 3 means SubPC derivatives are excited to a singlet excited state ${ }^{*}$ SubPC by absorbing laser pulse. Equations 4 and 5 mean the nonradiative and radiative deactivation of $*$ SubPC, respectively. And then, the *SubPC reacts with TCT to form chloro and dichlor omethyl radicals as shown in Equation 6. Further, the *SubPC becomes triplet state by intersystem crossing by Equation 7. The (SubPC-iTCT) is also excited to singlet (*SubPC-iTCT) by absorbing laser pulse (Equation 8 ). The activated (*SubPC-iTCT) takes statically

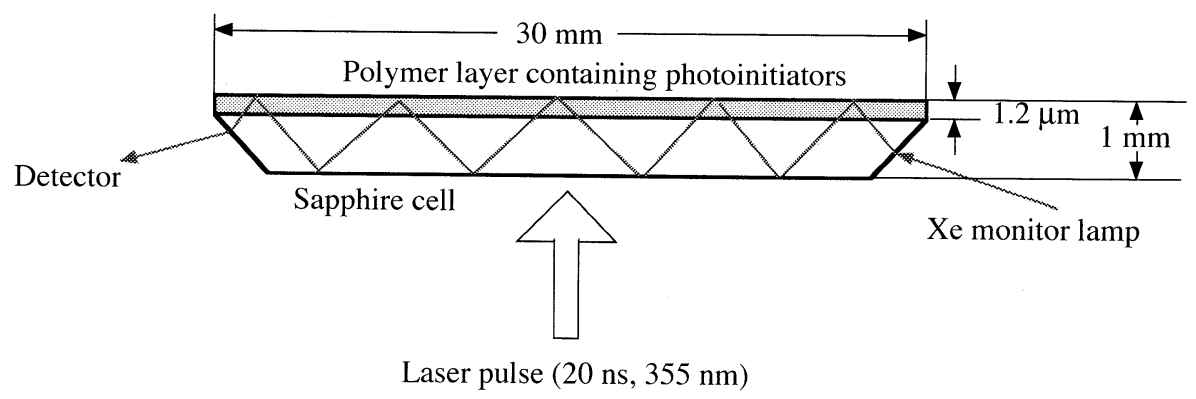

Fig. 1 Cell for laser flash photolysis in film. 


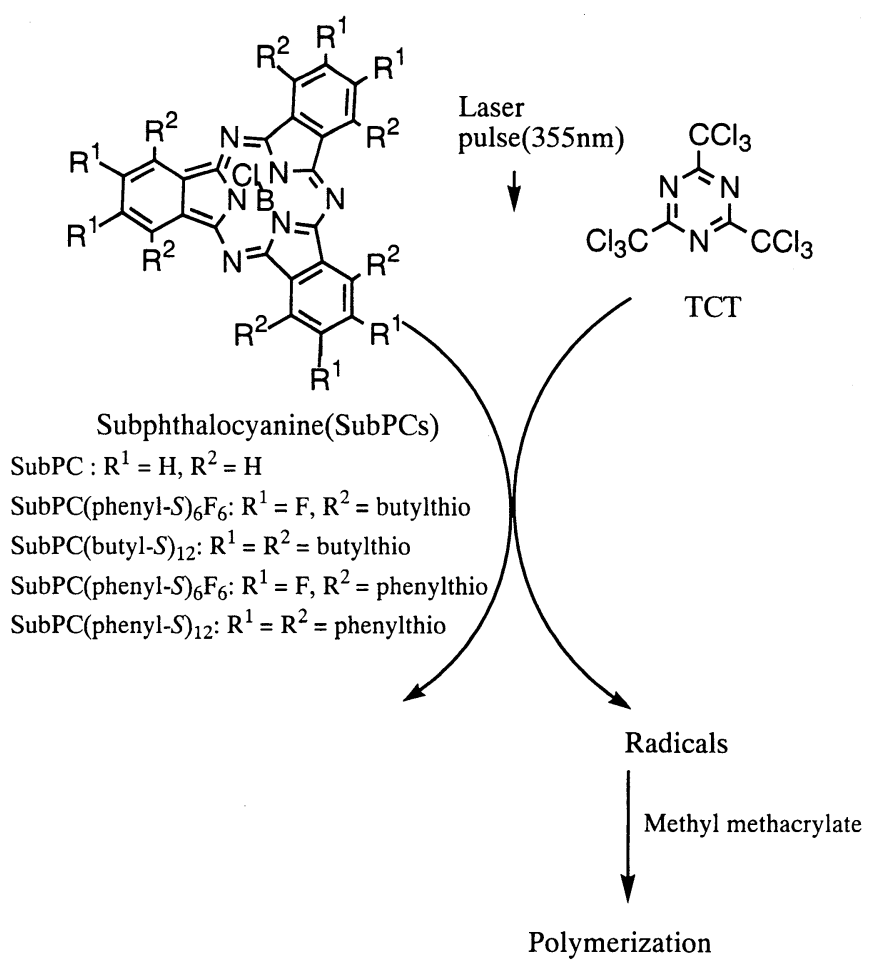

Fig. 2 Photoinitiation system of laser flash photolysis.
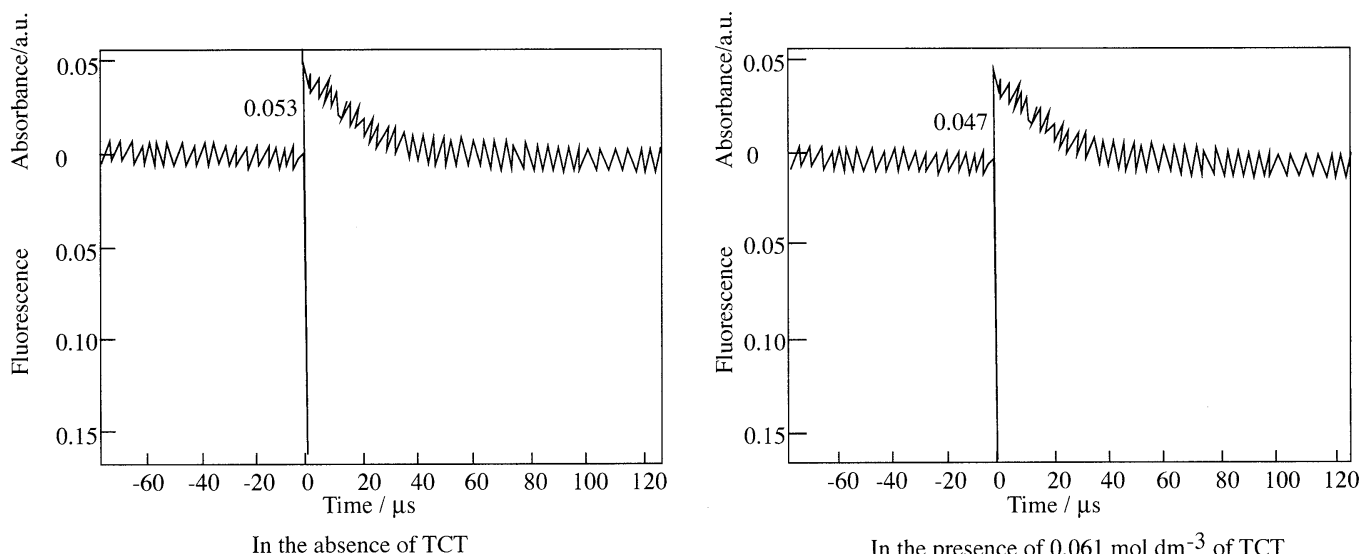

Fig. 3 Decay trace of subphthalocyanine at $450 \mathrm{~nm}$. Substance concentration ; $0.15 \mathrm{~mol} \mathrm{dm}^{-3}$. Excitation wavelength ; $355 \mathrm{~nm}$.
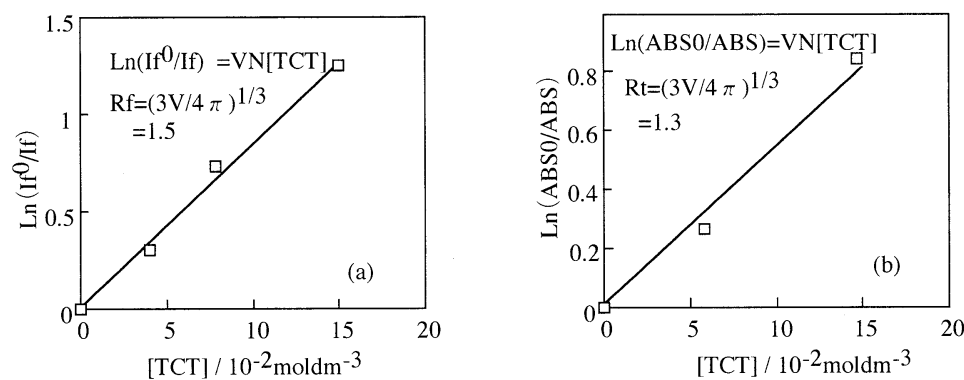

Fig. 4 Quenching of subphthalocyanine by 2, 4, 6-trin(trichloromethyl)-1,3,5-triazine in poly (methyl methacrylate). (a) Fluoresence at $572 \mathrm{~nm}$. Substance concentration ; $0.03 \mathrm{~mol} \mathrm{dm}^{-3}$.

Excitation wavelength ; $550 \mathrm{~nm}$.

(b) Triplet absorption intensity at $450 \mathrm{~nm}$. Substance concentration; $0.15 \mathrm{~mol} \mathrm{dm} \mathrm{dm}^{-3}$. Excitation wavelenght ; $355 \mathrm{~nm}$. 


$$
\begin{aligned}
& \mid \text { SubPC }-(\mathrm{i}-1) \mathrm{TCT} \mid+\mathrm{TCT} \stackrel{\mathrm{K}_{\mathrm{i}}}{\longrightarrow} \text { (SubPC-iTCT) } \mathrm{i}=1,2,3 \ldots \\
& \mathrm{Ki}=|\mathrm{SubPC}-\mathrm{iTCT}| /\{|\mathrm{SubPC}||\mathrm{SubPC}-(\mathrm{i}-1) \mathrm{TCT}|\}, i=1,2,3 \ldots \\
& \text { SubPC } \stackrel{\text { ho }}{\longrightarrow} * \text { SubPC } \\
& \text { *SubPC } \stackrel{\mathrm{k}_{\mathrm{d}}}{\longrightarrow} \text { SubPC } \\
& \text { *SubPC } \stackrel{\mathrm{kf}_{\mathrm{f}}}{\longrightarrow} \text { SubPC }+\mathrm{hv}_{\mathrm{f}} \\
& \text { *SubPC }+\mathrm{TCT} \stackrel{\mathrm{k}_{\mathrm{q}}}{\longrightarrow} \mathrm{SubPC}+\text { radicals } \\
& \text { *SubPC } \quad \stackrel{\mathrm{k}_{\text {isc }}}{\longrightarrow} \text { Triplet } \\
& \text { (SubPC-iTCT) } \stackrel{\text { hv }}{\longrightarrow}\left({ }^{*}\right. \text { SubPC-iTCT) } \\
& \text { (*SubPC-iTCT) } \stackrel{\mathrm{kq}^{\mathrm{i}}}{\longrightarrow}(\text { SubPC+(i-1)TCT) }+ \text { radicals }(9) \\
& \text { (*SubPC-iTCT) } \stackrel{\mathrm{kf}^{\mathrm{i}}}{\longrightarrow} \text { (SubPC-iTCT) }+ \text { hvf } \\
& \text { (*SubPC-iTCT) } \stackrel{\mathrm{kd}^{\mathrm{i}}}{\longrightarrow} \text { (SubPC-iTCT) } \\
& \text { (*SubPC-iTCT) } \stackrel{\mathrm{k}_{\mathrm{isc}} \mathrm{i}}{\longrightarrow} \text { (Triplet-iTCT) } \\
& \left.\mathrm{I}_{\mathrm{f}} 0 / \mathrm{If}_{\mathrm{f}}=\left\{\left(1+\mathrm{k}_{\mathrm{q}} \tau_{\mathrm{f}} 0 \mathrm{TCT}\right]\right)\left(\mathrm{X}+\mathrm{k}_{\mathrm{q}} \tau_{\mathrm{f}}{ }^{0}\right)\right\} /\{\mathrm{X}+ \\
& \left.\left.\mathrm{kq}_{\mathrm{q}} \tau_{\mathrm{f}} \mathrm{O} \mid \mathrm{TCT}\right]+\left\{\mathrm{Xk}_{\mathrm{q}} \mathrm{i}_{\mathrm{f}} \mathrm{f}^{0}-\mathrm{kq}_{\mathrm{q}} \tau_{\mathrm{f}} \mathrm{O}^{0} \mid \mathrm{TCT}\right] \exp (-\mathrm{VN}|\mathrm{TCT}|)\right\} \\
& \mathrm{If}_{\mathrm{f}} 0 / \mathrm{I}_{\mathrm{f}}=\left(1+\mathrm{k}_{\mathrm{q}} \tau_{\mathrm{f}} \mathrm{f}^{\mathrm{T}} \mathrm{TCT} \mid \exp (\mathrm{VN}|\mathrm{TCT}|)\right.
\end{aligned}
$$

where, If 0 and If are the fluorescence intensities in the absence and presence of the radical generator TCT, $\tau_{f} 0$ is the lifetime in the absence of radical generator, $\mathrm{k}_{\mathrm{q}}$ is the dynamic quenching rate constant, $\mathrm{kq}_{\mathrm{q}} \mathrm{i}$ is the static quenching constant, $\mathrm{V}$ is the quenching sphere, $\mathrm{V}=4 \pi R f / 3, N$ is Avogadro's number, $\mathrm{Rf}$ is the quenching radius and $\mathrm{X}=\mathrm{Ki} \Sigma|(\mathrm{SubPC}-(\mathrm{i}-1) \mathrm{TCT})|+1$.

Scheme 1 The multistep equilibrium between SubPC derivatives and TCT.

sensitized decomposition of TCT (Equation 9). Then, (*SubPC-iTCT) undergoes radiative and non-radiative deactivation and intersystem crossing as described in Equations 10-12. The intensity of fluorescence with the concentration of TCT in film is described as Equation 13. When (*SubPC-iTCT) does not emit fluorescence, meaning $\mathrm{kq}^{\mathrm{i}}$ is much larger than any other decay rate, Equation 13 is described as Equation 14 of dynamic and static quenching term.

The triplet state of SubPC in PMMA films was also generated by radicals from TCT. The initial absorbance was decreased with increasing concentration of TCT. The triplet lifetimes of SubPC derivatives were measured to be almost same. The logarithmic plots of the initial absorbance at various concentration of TCT were fitted to the Perrin equation, the triplet quenching radius ( $\mathrm{Rt}$ ) were calculated to be $1.3 \mathrm{~nm}$, which was almost same as Rf $1.5 \mathrm{~nm}^{10,11)}$. Both Rt and Rf describe electron transfer properties, which are recognized as an efficient mechanism for quenching ${ }^{10,11)}$.

The results indicate the triplet initial absorption was not quenched by TCT, because the triplet state generally comes from the fluorescent singlet state, and the triplet is apparently reduced with the decrease of the singlet state.

SubPC has two irreversible oxidation and reduction at 0.82 and $-0.30 \mathrm{~V}$ vs. $\mathrm{Ag} / \mathrm{AgCl}$, and one pair of reversible reduction potential at $-0.64 \mathrm{~V}$ vs. $\mathrm{Ag} /$

$\mathrm{AgCl}^{1}$ ). In general, oxidations of transition metal phthalocyanine derivatives are electrochemically irreversible, and the potential is about $1.0 \mathrm{~V}$ vs. standard hydrogen electrode ${ }^{13,14)}$.

The reduction and oxidation behavior of metal phthalocyanine derivatives are attributed to the interaction between the phthalocyanine ring and the central metal $^{14)}$. In the case of metal phthalocyanine derivatives, the porphyrazine ring in the molecule is influenced by the $\pi$ electrons around the closed system. The 18 $\pi$ electron system of metal phthalocyanine derivatives consists of one porphyrazine and four phenylene rings ${ }^{3,15,16)}$. Substituents of metal phthalocyanine derivatives influence the $18 \pi$ electron environment in the molecule of the four phenylene rings, and are depending on electron-transfer properties of metal phthalocyanine derivatives. While in the case of SubPC and its derivatives, redox potentials had various values which were independent from nature and number of substituents. It implies the possibility of electron-transfer from the singlet excited state of SubPC to the ground state of TCT. SubPC derivatives have similar phenomena to SubPC. The photoinitiation process of SubPC and its derivatives may occur independently of the substituents, because the substituents can undergo the strong ring current effect of SubPC.

It is suggested that the static-singlet-quenching process from the singlet photoexcited SubPC to TCT is predominant in the sensitization.

\section{Conclusions}

In this study, photosensitizing properties of SubPC derivatives in PMMA films was investigated.

The results indicated the triplet initial absorption was not quenched by TCT, since the triplet state generally came from the fluorescent singlet state, and the triplet state is apparently reduced with the decrease of the singlet state.

The reduction potential of SubPC was obserbed at $0.64 \mathrm{~V}$ vs. $\mathrm{Ag} / \mathrm{AgCl}$ and the oxidation potential appeared at $0.82 \mathrm{~V}$ vs. $\mathrm{Ag} / \mathrm{AgCl}$. It implies the possibility of electron-transfer from the singlet excited state of SubPC to the ground state of TCT. SubPC derivatives have similar phenomena to SubPC.

It is suggested that the static-singlet-quenching process from photoexcited SubPC to TCT is predominant in the sensitization.

\section{References}

1) E. Ohno-Okumura, K. Sakamoto, T. Urano : J. Jpn. Soc. Colour Mater., 75, 255 (2002). 
2) K. Sakamoto, E. Ohno: J. Soc. Dyeres Col., 112, 368 (1996).

3) K. Sakamoto, E. Ohno : Prog. Org. Coat., 31, 139 (1997).

4) E. Ohno, K. Sakamoto: J. Chem. Soc. Jpn., 1995, 730 .

5) E. Ohno, K. Sakamoto : J. Chem. Soc. Jpn., 1997, 58.

6) T. Urano, K. O. Nguyen, H. Nagasaka, M. Tsuchiya, S. Shimizu, H. Itoh, Y. Senda : Bull. Chem. Soc. Jpn., 67, 1074 (1994).

7) T. Urano, E. Ohno-Okumura, K. Sakamoto, H. Itoh, T. Yamaoka: J. Photopolymer Sci. Tech., 12, 747 (1999).

8) M. Geyer, F. Plenzig, J. Rauschanbel, M. Hanack, B. D. Rey, A. Satre, T. Torres: Synthesis., 1996, 1139.
9) J. B. Birks : Photophysics of Aromatic Molecules. Wiley, (1970). p. 441.

10) J. R. Miller, J. A. Peeples, M. J. Schmitt, G. L. Closs: J. Am. Chem. Soc., 104, 6488(1982).

11) K. Nagai, J. Tsukamoto, N. Takamiya, M. Kaneko:J. Phys. Chem., 99, 6648(1995).

12) D. Lexa, M. Reix : J. Chem. Phys. Physicochem. Boil., 1974 ; 71, 511(1974).

13) A. Wolberg, J. Manassen : J. Am. Chem. Soc., 92, $2982(1970)$.

14) A. B. P. Lever, S. Licoccis, K. Magrell, P. C. Minor, B. S. Remananey : Adv. Chem. Ser., 201, 237 (1982).

15) K. Sakamoto, E. Ohno: Dyes and Pigments., 35, 375(1997).

16) K. Sakamoto, E. Ohno: Dyes and Pigments., 37, 291 (1998).

ポリ (メタクリル酸メチル) フィルム中におけるサブフタロシアニン誘導体の光増感特性

大野 (奥村) 映子*・坂本恵一**・浦野年由 ${ }^{* * *}$

*化学技術教育研究所 千葉県船橋市習志野台 8-37-1 （产 274-0063）

**日本大学生産工学部応用分子化学科 千葉県習志野市泉町 1-2-1 (T 275-8575)

***千葉大学工学部共同利用センター 千葉県千葉市稲毛区弥生町 1-33 (T 263-8522)

三菱化学株式会社科学技術研究センター 神奈川県横浜市青葉区鴨志田町 1000 （テ 227-8502）

要旨

前報にて合成を報告したフルオロ基，フェニルチオ基，ブチルチオ基を導入したサブフタロシアニン誘導体 6 種類について， 増感特性を測定した。サブフタロシアニン誘導体の増感特性は，ラジカル発生剤としての 2, 4, 6-トリス（トリクロロメチル）1，3，5-トリアジンを加えたポリ（メタクリル酸メチル）フィルムにてレーザーフラッシュフォトリシスにて測定した。 